\title{
UPAYA PENINGKATAN ANGKA PARTISIPASI PESERTA DIDIK MELALUI PROGRAM SOSIALISASI TERPADU
}

\author{
Sutopo \\ SDN Condong I Kec. Gading \\ Email: sutopobroto60@gmail.com
}

\begin{abstract}
Abstrack: inwrought socialization program execution in this watchfulness achieve aim or target that appointed, because this program applications effectively proved give impact and influence enough significant towards entrant participation number enhanced educates at sd source country dumpyong 1 regency bondowoso. this program must then be carried out chronically so that government program in order to speed up obligatory successful learn education base 9 year complete
\end{abstract}

Key word: partisipasi, peserta didik, sosialisasi terpadu

Pembukaan Undang-undang Dasar Negara Republik Indonesia tahun 1945 mengamanatkan bahwa pemerintah menyelenggarakan sistem pendidikan nasional dalam rangka memajukan kesejahteraan umum, mencerdaskan kehidupan bangsa, menjamin pemerataan kesempatan pendidikan, peningkatan mutu serta relevansi dan efisiensi manajemen pendidikan untuk menghadapi tantangan perubahan kehidupan lokal, nasional, dan global. Penyelenggaraan pembangunan di bidang pendidikan merupakan kewajiban pemerintah dengan memberdayakan seluruh komponen masyarakat agar tujuan pendidikan dapat tercapai. Tujuan pendidikan nasional yakni mengembangkan potensi peserta didik agar menjadi manusia yang beriman dan bertakwa kepada Tuhan Yang Maha Esa, berakhlak mulia, sehat, berilmu, kreatif, mandiri, demokratis, dan bertanggung jawab.

Pemerintah melalui Inpres nomor 5 tahun 2006 telah mensosialisasikan Gerakan Nasional Percepatan Penuntasan Wajib Belajar Pendidikan Dasar 9 tahun. Diharapkan program ini akan memenuhi target angka serapan anak usia 13 sampai 15 tahun yang melanjutkan ke SMP dapat mencapai $95 \%$ pada tahun 2015/2016. Upaya-upaya pemerintah diantaranya dengan membangun unit sekolah baru, menambah ruang kelas baru, memberikan bantuan operasional sekolah, dan lain-lain. Selain itu untuk pemerataan dan perluasan akses guna mempercepat program penuntasan wajib belajar seperti yang telah diuraikan di atas, pemerintah juga mengembangkan dan menambah jumlah SD, serta mendirikan sekolah SD-SMP satu atap terutama di daerah-daerah terpencil.

Direktorat Pembinaan Sekolah Dasar (PSD) melalui sekolah sebagai salah satu bentuk satuan pendidikan juga mengupayakan adanya peningkatan mutu pelayanan dan sosialisasi program-program percepatan kepada masyarakat 
dengan melibatkan semua komponen terkait, terutama peran komite sekolah dan tokoh masyarakat.Namun demikian kendala-kendala yang dihadapi sekolah masih cukup banyak dan beragam, selain faktor pengalokasian dana pendidikan oleh pemerintah yang belum mencapai $20 \%$ sesuai dengan amanat undang-undang dasar, juga disebabkan kurangnya pemahaman masyarakat terhadap pentingnya pendidikan sehingga program percepatan penuntasan wajib belajar 9 tahun menjadi banyak menemui kendala. Untuk itu pengelola lembaga pendidikan berkewajiban melaksanakan standar pelayanan minimal dalam penyelenggaraan pendidikan serta dapat menerapkan strategi pengelolaan dan pelayanan pendidikan yang bermutu sesuai dengan Standar Nasional Pendidikan (Peraturan Pemerintah RI Nomor 19 Tahun 2005).

SD Negeri Condong I Kec.Gading Kabupaten Probolinggo adalah lembaga Pendidikan yang terletak di daerah pedesaan dengan sumber daya manusia (SDM) sangat rendah, dan kondisi ekonomi masyarakat mayoritas miskin, serta animo terhadap pendidikan masih sangat rendah. Adapun faktorfaktor penyebabnya antara lain: 1) kurangnya pemahaman masyarakat terhadap arti pentingnya pendidikan, 2) masih belum efektifnya sosialisasi dan gerakangerakan penuntasan wajar dikdas 9 tahun oleh lembaga dan instansi terkait, 3) kentalnya budaya masyarakat yang kurang mendukung partisipasi terhadap pendidikan,utamanya pendidikan formal (umum). Untuk itulah perlu ada upayaupaya sekolah untuk melakukan sosialisasi secara intensif dan terpadu agar masyarakat mendapatkan informasi yang cukup tentang pentingnya pendidikan yang akhirnya masyarakat merasakan bahwa pendidikan adalah sebuah kebutuhan yang dapat mengantarkan peserta didik guna meningkatkan sumber daya yang semakin kompetitif .

\section{METODE}

Pelaksanaan tindakan direncanakan berlangsung sebanyak 2 siklus. Tahapan-tahapan masing-masing siklus penelitian meliputi: perencanaan, pelaksanaan, pengamatan, dan refleksi.

Untuk memperoleh data yang objektif dan akurat, maka prosedur pengumpulan data dipergunakan triangulasi data, artinya data-data diperoleh dari 3 sumber antara lain dari :1.Petugas Pelaksana, berupa data tingkat kehadiran peserta sosialisasi. 2.Kolaborator yaitu instansi terkait, berupa catatan lapangan dan lembar observasi selama kegiatan sosialisasi berlangsung. 3.Masyarakat, berupa angket atau kuisioner yang diisi untuk memberikan respon.

\section{Siklus I}

\section{Perencanaan Tindakan (Planning)}

Agar pelaksanaan berhasil dengan baik, maka perlu dirancang dan dipersiapkan secara matang serta menyeluruh termasuk penyiapan instrumen penelitian. Hal-hal yang disiapkan meliputi: (1) Penetapan petugas sosialisasi atau kelompok kerja yang terdiri dari gabungan Guru TK, Guru SD, Lembaga masyarakat di Desa seperti: BPD, LPMD, PKK, Dasa Wisma, dan instansi terkait. (2) Penyusunan jadwal sosialisasi dan tempat sasaran/lokasi sosialisasi. (3) Penyusunan instrumen penelitian meliputi angket/kuisioner, lembar observasi, dan 
catatan lapangan/rekaman. (d) Menyampaian surat pemberitahuan pelaksanaan sosialisasi.

\section{Pelaksanaan Tindakan (Acting)}

Petugas melakukan sosialisasi secara terpadu di Sekolah-sekolah TK, baik di sekitar SD maupun yang berada di tempat yang jauh / pelosok sesuai jadwal yang ditetapkan. b.Sosialisasi tentang akses pendidikan dan Program Wajib Belajar Pendidikan Dasar 9 disampaikan kepada wali murid dan siswa, khususnya TK.Bentuk penyampaiannya berupa presentasi tentang program-program sekolah serta bantuan pemerintah terhadap siswa miskin dan terpencil .

Sosialisasi juga berbentuk dialog interaktif guna menampung aspirasi masyarakat dan keluhan masyarakat untuk dicarikan solusi dan ditindak lanjuti. Pendataan terhadap para lulusan TK yang sudah melanjutkan dan juga pendataan pada siswa yang belum melanjutkan / menganggur di rumah, baik oleh Kepala Sekolah, Ibu-ibu Dasawisma,PKK, dan ketua RT/RW.

\section{Pengamatan (Observing)}

Pada saat sosialisasi berlangsung, kolaborator yang dalam hal ini adalah lembaga masyarakat melakukan pengamatan terhadap aktivitas sosialisasi yang dilakukan guru bersama tokoh masyarakat dan instansi terkait, dengan menggunakan lembar observasi. Pengamatan meliputi : Efektivitas pelaksanaan sosialisasi berupa dialog interaktif dengan masyarakat, Respon masyarakat terhadap program-program sekolah serta bantuan pemerintah, Mencatat permasalahan dan hambatan-hambatan yang muncul selama pelaksanaan sosialisasi.

\section{Refleksi (Reflecting)}

Pada tahap refleksi, guru bersama kolaborator mendiskusikan, menganalisis, dan mengambil kesimpulan. Kegiatan yang dilakukan adalah : Menganalisis data hasil pelaksanaan siklus 1, Mengidentifikasi temuan-temuan selama kegiatan berlangsung, Menetapkan alternatif pemecahan masalah untuk perbaikan dan sekaligus dijadikan dasar pada perencanaan siklus berikutnya

\section{SIKLUS II}

\section{Perencanaan Tindakan (Planning)}

Agar pelaksanaan berhasil dengan baik, maka perlu dirancang dan dipersiapkan kembali secara matang serta menyeluruh termasuk penyiapan instrumen penelitian. Hal-hal yang disiapkan meliputi :Pemantapan petugas sosialisasi atau kelompok kerja yang terdiri dari gabungan Guru TK, Guru SD, Lembaga masyarakat di Desa seperti : BPD, LPMD, PKK, Dasa Wisma, dan instansi terkait. Perbaikan jadwal sosialisasi dan tempat sasaran/lokasi sosialisasi. Penggandaan instrumen penelitian meliputi angket / kuisioner, lembar observasi , dan catatan lapangan / rekaman . Menyampaian surat pemberitahuan pelaksanaan sosialisasi. 


\section{Pelaksanaan Tindakan (Acting)}

Petugas melakukan sosialisasi secara terpadu di Mosholla-musholla dan Balai Desa sesuai jadwal yang ditetapkan. Sosialisasi tentang akses/pemerataan pendidikan dan Program Wajib Belajar Pendidikan Dasar 9 disampaikan kepada wali santri dan masyarakat. Bentuk penyampaiannya berupa presentasi tentang program-program sekolah serta bantuan pemerintah terhadap siswa miskin dan terpencil . Sosialisasi juga berbentuk dialog interaktif guna menampung aspirasi masyarakat dan keluhan masyarakat untuk dicarikan solusi dan ditindak lanjuti. Pendataan terhadap para lulusan TK yang sudah melanjutkan dan juga pendataan pada siswa yang belum melanjutkan / menganggur di rumah, baik oleh para guru ngaji maupun tokoh masyarakat/komite.

\section{Pengamatan (Observing)}

Pada saat sosialisasi berlangsung, kolaborator yang dalam hal ini adalah lembaga masyarakat melakukan pengamatan terhadap aktivitas sosialisasi yang dilakukan guru bersama tokoh masyarakat dan instansi terkait, dengan menggunakan lembar observasi. Pengamatan meliputi: Efektivitas pelaksanaan sosialisasi berupa dialog interaktif dengan masyarakat. Respon masyarakat terhadap program-program sekolah serta bantuan pemerintah.

Mencatat permasalahan dan hambatan-hambatan yang muncul selama pelaksanaan sosialisasi.

\section{Refleksi (Reflecting)}

Pada tahap refleksi, guru bersama kolaborator mendiskusikan, menganalisis, dan mengambil kesimpulan. Kegiatan yang dilakukan adalah : Menganalisis data hasil pelaksanaan siklus 2, Menetapkan alternatif pemecahan masalah serta menindaklanjuti temuan-temuan di lapangan

\section{HASIL}

Disajikan deskripsi hasil penelitian, analisis data, dan pengujian hipotesis. Dari deskripsi tersebut akan dijabarkan hasil dari pelaksanaan Program Sosialisasi Terpadu (PST) dengan melibatkan komponen sekolah dan komponen terkait guna meningkatkan angka partisipasi peserta didik di SD Negeri Condong I Kec.Gading Kabupaten Probolinggo.

\section{Siklus I}

Pelaksanaan Sosialisasi dilakukan pada sekolah Taman Kanak Kanak (TK) baik yang berlokasi dekat dengan SD Negeri Condong I Kec.Gading maupun TK yang secara georafis sangat jauh dan terpencil. Pelaksana sosialisasi terdiri dari masing-masing satu orang guru SD, pengurus Komite,Ketua RT/RW, dan Tokoh Masyarakat setempat. Peserta sosialisasi adalah wali murid dan juga diikuti oleh siswa. Setelah penyampaian materi, komite melakukan dialog interaktif dengan masyarakat tentang kendala-kendala yang dihadapi masyarakat dalam rangka pemerataan kesempatan mengikuti pendidikan tingkat SD atau yang sederajat. Peserta sosialisasi dibagikan angket/kuesioner untuk memberikan respon terhadap program-program pendidikan serta pemerataan kesempatan 
memperoleh pendidikan guna sukse wajar dikdas 9 tahun. Respon masyarakat diagendakan untuk ditindak lanjuti, diantaranya ada sebagian wali murid yang langsung mendaftarkan putranya untuk masuk ke SD, sebagian lagi tetap akan melanjutkan ke pesantren.

\section{Siklus II}

Pelaksanaan Sosialisasi dilakukan pada musholla-musholla yang memiliki santri Usia TK. Pelaksana sosialisasi terdiri dari masing-masing satu orang guru SD, pengurus Komite, Ketua Dasa wisma di lingkungan tersebut. Peserta sosialisasi adalah wali santri dan juga diikuti oleh warga sekitar. Setelah penyampaian materi, komite melakukan dialog interaktif dengan masyarakat tentang kendala-kendala yang dihadapi masyarakat dalam rangka pemerataan kesempatan mengikuti pendidikan tingkat SD atau yang sederapat. Respon masyarakat diagendakan untuk ditindak lanjuti, diantaranya ada sebagian wali santri yang langsung mendaftarkan putranya untuk melanjutkan ke SD dan sekolah menjanjikan sekolah gratis khusus bagi masyarakat miskin

Secara umum pelaksanaan sosialisasi berlangsung dengan baik, dan respon masyarakat juga positif setelah mendapatkan informasi tentang kemudahankemudahan untuk masuk ke jenjang SD, khususnya bantuan biaya yang diberikan oleh pemerintah. Namun demikian masih banyak permasalahan yang dihadapi sekolah guna meningkatkan angka partisipasi kasar (APK) sehingga dapat mencapai minimal $90 \%$.

\section{PEMBAHASAN}

\section{Tahap Pengumpulan Data}

Dalam penelitian ini, peneliti mengumpulkan data dari hasil opini dan jawaban dari responden yang termuat dalam kuesioner yang disebar kepada beberapa sekolah dasar di lingkungan Cabang dinas Pendidikan Kecamatan Gading Kabupaten Probolinggo . Selain itu pengumpulan data juga didukung dengan data hasil kegiatan observasi, wawancara, dan kuesioner yang berupa daftar pertanyaan untuk dijawab oleh responden baik secara langsung maupun jawaban yang dilakukan dengan panduan peneliti.Data yang terkumpul selanjutnya dipersiapkan ke tahap pengolahan data. Data dari kuesioner, wawancara, dan hasil observasi ditujukan langsung kepada responden untuk menilai secara objektif hasil dari pelaksanaan Program Sosialisasi Terpadu (PST).

\section{Deskripsi Hasil Penelitian.}

Responden diambil dari beberapa sekolah dan kepala sekolah yang digunakan sebagai sample penelitian yang dipilih secara representatif untuk mewakili seluruh responden.

\section{KESIMPULAN}

Berdasarkan hasil analisis data dan pembahasan ,maka dapat disimpulkan sebagai berikut: (1) Pengumpulan data dari 12 responden berupa jawaban atas pertanyaan atau pernyataan pada kuesioner menyimpulkan bahwa secara umum 
pelaksanaan sosialisasi berjalan baik dan lancer, animo masyarakat terhadap pendidikan menunjukkan adanya peningkatan, ini terbukti dari jumlah siswa yang melanjutkan mengalami kenaikan sebesar $50 \%$ dari tahun sebelumnya, yaitu dari 8 siswa yang diterima, untuk tahun pelajaran 2014/2015 menjadi 15 siswa baru yang diterima pada TP.2015/2016. (2) Pelaksanaan Program Sosialisasi Terpadu dalam penelitian ini telah mencapai tujuan atau sasaran yang ditetapkan, karena penerapan program ini secara efektif terbukti telah memberikan dampak dan pengaruh yang cukup signifikan terhadap peningkatan angka partisipasi peserta didik di SD Negeri Condong I Kec.Gading Kabupaten Probolinggo.

\section{SARAN}

Program ini harus terus dilaksanakan secara berkesinambungan agar program pemerintah dalam rangka mempercepat sukses wajib belajar pendidikan dasar 9 tahun akan tuntas.

\section{DAFTAR RUJUKAN}

Depdikbud. 1994. Pembangunan Pendidikan dan Kebudayaan Menjelang Era Tinggal Landas. Jakarta : Depdikbud.

Engkoswara. 2001. Paradigma Manajemen Pendidikan Menyongsong Otonomi Daerah. Bandung : Yayasan Amal Keluarga.

Mulyasa, Enco. 2006. Menjadi Kepala Sekolah Profesional. Bandung : PT Remaja Rosdakarya.

Pelangi Pendidikan. 2008. Deklarasi Penuntasan Wajib Belajar Pendidikan Dasar Sembilan Tahun. Jakarta : Depdiknas

Sagala, Syaiful. 2007. Manajemen Strategik Dalam Peningkatan Mutu Pendidikan. Bandung : Penerbit Alfabeta.

Saukah ,Ali,Dkk. 2000. Pedoman Penulisan Karya Ilmiah. Malang : UM Press.

Tilaar, H.A.R. 1994. Manajemen Pendidikan Nasional Kajian Pendidikan Masa Depan. Bandung : Remaja Rosdakarya. 